\title{
TECHNOGENIC IMPACT OF SULPHIDE-CONTAINING WASTES PRODUCED BY ORE MINING AND PROCESSING AT THE OZERNOE DEPOSIT: INVESTIGATION AND FORECAST
}

\author{
Maria A. Pashkevich', Tatyana A. Petrova' \\ 1 Saint-Petersburg Mining University, Vasilievskiy Island 21 \\ Federation, e-mail: mpash1963@yandex.ru, petrova9@yandex.ru
}

Received: 2017.08 .28

Accepted: 2017.09.30

Published: 2017.11.01

\begin{abstract}
The paper provides an assessment of the potential technogenic impact of sulphidecontaining wastes produced by ore extraction and processing at the Ozernoe deposit, which is currently at the initial stage of mining. The analysed averaged samples of ore and wastes of mining and processing were obtained in the course of semi-industrial experimental preproduction. The results of monitoring studies in the area of sulphidecontaining dumps formed at an exploring mine in the 1960s were used for assessing a potential hazard of the wastes. The origin of acid mine drainage is described. Advantages and shortcomings of tests assessing acid mine drainage are considered. The used express-method of acid indication allows to reliably determine the risk of acid mine drainage by the values of acidic and neutralising potentials formed by rocks. An estimation of acid mine drainage formation and heavy metal migration is carried out at dumps of the exploring mine. The forecast of environmental impact is given for the future wastes of mining and processing at the Ozernoe deposit.
\end{abstract}

Keywords: dumps of sulphide-containing wastes; adverse impact; environmental hazard; acid mine drainage; express-method of acid indication.

\section{INTRODUCTION}

The negative environmental impact of mining enterprises raises annually (Bwapwa et al., 2017; Pashkevich, Petrova, 2017; Simate, Ndlovu, 2014). This is due to an objectively increased consumption of material resources by mankind (Alekseenko et al., 2017a; Beloglazov et al., 2014; Cehlár et al., 2016; Gumenik et al., 1988; Pashkevich, 2017). In modern extraction conditions, the output of finished products is less than $10 \%$; the rest is made of mining and processing wastes, which occupy hundreds of thousands of hectares (Pashkevich, Petrova, 2015; Pavolová et al., 2016). Mineral mining wastes contain, as a rule, components that are open-stored and exposed to climatic factors and can transform into new compounds and migrate to tens and hundreds of kilometres from their source (Alekseenko et al., 2017b; Grudev, 1995; Kefeni et al., 2017).
The natural environment is subjected to the maximum technogenic load in the areas where sulphide-containing wastes are stored. Formation of acid mine drainage (AMD) waters and, respectively, litho- and hydrogeochemical pollution haloes with extremely low $\mathrm{pH}$ values is caused by oxidation of sulphide sulphur (Favas et al., 2016; Han et al., 2017; Nleya et al., 2016). This destructs vegetation, transforms the composition of surface sediments, surface, and ground waters. Therefore, the development and implementation of environmental protection measures to prevent the effects of sulphide-containing wastes on nearsurface sediments and natural waters is necessary at the design stage and initial exploitation periods of sulphide ore mining.

The Ozernoe deposit of polymetallic sulphide ores, which is located $350 \mathrm{~km}$ from the specially protected area of Lake Baikal, is currently at the initial mining stage. The deposit mining will pro- 
duce over 600 million tons of wastes containing sulphide sulphur and heavy metals, which are simultaneously pollutants and potential mineral raw materials. In this regard, it is necessary to assess and predict the AMD formation in areas of mineral waste storage in order to prevent acidification.

\section{MATERIALS AND METHODS}

Lead-zinc ore mineralization of the Ozernoe deposit is represented by a series of stacked and lenticular pyrite-siderite-polymetallic ore bodies arranged one above the other. The ores have pyrite-lead-zinc mineral composition. Pyrite, sphalerite, and, to a lesser extent, galena are the main ore minerals.

A distinctive feature of the deposit is the leadzinc composition of ores with almost complete absence of copper; the ratio $\mathrm{Pb}: \mathrm{Zn}: \mathrm{Cu}$ is 1:6:0.05. The ores of the deposit contain zinc, lead, and sulphur in economic valuable concentrations; silver and cadmium are useful associated components. According to calculations, a designed plant will annually process 8 million tons of mined ores. After enriching, three concentrates are planned to be obtained:

- zinc concentrate;

- lead concentrate;

- pyrite concentrate.

Under laboratory conditions, the averaged ore samples, technological samples of zinc, lead, and pyrite concentrates, as well as tail specimens, obtained after a semi-industrial pilot production experiment, were examined. The chemical composition of the samples was determined by the X-ray fluorescence Shimadzu spectrometer XRF-1800 and the atomic absorption Shimadzu spectrophotometer AA-7000. The test results are given in Table 1.

The conducted studies showed that after enriching polymetallic ores of the Ozernoe deposit the following wastes in the total volume over 16 million $\mathrm{m}^{3}$ would be stored in the oxidizing environment: pyritic concentrate $\left(\mathrm{S}_{\text {suph }}\right.$ content is over $43 \%)$ and dump tails $\left(\mathrm{S}_{\text {suph }}\right.$ content is over $9 \%$ ). In addition, over 25 million $\mathrm{m}^{3}$ of waste rocks, which contain $7 \%$ of $\mathrm{S}_{\text {suplh }}$ at average, will be formed during ore extraction.

Monitoring studies near the Ozernoe deposit were carried out to assess the potential danger of sulphide-containing wastes at the exploration mine worked out in the 1960s. The storage of sulphide-containing waste rocks around the exploration mine occupies 1 ha.

Four transects crossed the dumps, where averaged surface samples were taken by the envelope method from a depth of 10-15 cm [Fedorets, Medvedeva, 2009]. Each spot $2 \times 1 \mathrm{~m}$ in size was sampled at the square nodes and at the intersection of diagonals. Sample quartering was performed at each point to obtain a representative specimen.

The migration capacity of toxic impurities washed by precipitation from the dump site was estimated by examining the Bezymyanny stream that drains the dump, where bottom sediment sampling was carried out each $50 \mathrm{~m}$, before flowing into the Gunduy-Kholoy River at a distance of $1.5 \mathrm{~km}$. A cut was made in the waste rock body and 2 wells with a depth over $2 \mathrm{~m}$ were drilled to assess the vertical migration of polluting components. Description of the section made it possible to characterise the constituent rocks.

Analyses of the taken dump rock samples and bottom sediments were carried out using an X-ray powder diffractometer XRD-7000 (Shimadzu) to evaluate mineral composition. The bulk elemental composition of the samples was defined using $\mathrm{X}$-ray fluorescence method. A portable X-ray fluorescence spectrometer Niton Xlt 500 was used to analyse samples on site. A semiquantitative analysis of samples from the exploration mine of the Ozernoe deposit was carried out under laboratory conditions using an ED $2000 \mathrm{X}$-ray fluorescence spectrometer (Oxford Instruments, UK). To refine the results, an XRF-1800 wave-dispersive $\mathrm{X}$-ray fluorescence spectrometer (Shimadzu, Japan) was used. Determination of the contents of several potentially toxic elements was carried out using atomic absorption spectrometry and inductively coupled plasma spectrometry. Analytical works were carried out on an ICPE-9000 (Shimadzu) and an atomic absorption spectrometer AA6300 (Shimadzu, Japan).

\section{RESULTS}

The investigations showed that wastes of the exploration mine mainly consist of pyrite, siderite, calcite, dolomite (Table 2) with $4.5-25.0 \mathrm{~g} / \mathrm{kg}$ content of $\mathrm{Pb}, 13-35 \mathrm{~g} / \mathrm{kg}$ of $\mathrm{Zn}, 170-240 \mathrm{~g} / \mathrm{kg}$ of $\mathrm{S}, 215-640 \mathrm{mg} / \mathrm{kg}$ of As, $180-320 \mathrm{mg} / \mathrm{kg}$ of $\mathrm{Cu}, 40-115 \mathrm{mg} / \mathrm{kg}$ of $\mathrm{Cd}$. Contrast secondary lithochemical halos of zinc, lead and other heavy 
Table 1. Results of laboratory tests of ores, tailings, and zinc, lead and pyrite concentrates

\begin{tabular}{|c|c|c|c|c|c|}
\hline \multirow[b]{2}{*}{ Component } & \multicolumn{5}{|c|}{ Concentrations in products, $\%$} \\
\hline & $\begin{array}{l}\text { Unprocessed } \\
\text { ore }\end{array}$ & $\begin{array}{c}\text { Lead } \\
\text { concentrate }\end{array}$ & Zinc concentrate & $\begin{array}{c}\text { Pyrite } \\
\text { concentrate }\end{array}$ & Tailings \\
\hline Lead & 1.00 & 49.20 & 0.44 & 0.47 & 0.23 \\
\hline Zinc & 5.83 & 4.91 & 52.20 & $2.05 / 1.25$ & 0.57 \\
\hline Copper & 0.07 & 0.46 & 0.20 & 0.11 & 0.03 \\
\hline Iron & 26.33 & 13.83 & 8.15 & 38.57 & 22.35 \\
\hline Sulphur & 22.30 & 26.50 & 34.90 & 43.72 & 9.89 \\
\hline Cadmium & 0.01 & 0.011 & 0.10 & 0.0066 & not determined \\
\hline Gold, ppm & 0.16 & 1.2 & 0.20 & 0.10 & 0.1 \\
\hline Silver, ppm & 29.9 & 44.3 & 70.8 & 35.4 & 4.9 \\
\hline Thallium & 0.0029 & 0.0032 & 0.0011 & 0.0039 & 0.0045 \\
\hline Gallium & 0.00030 & 0.000078 & 0.00083 & 0.00015 & 0.00062 \\
\hline Germanium & not determined & not determined & not determined & not determined & not determined \\
\hline Indium & 0.00042 & 0.00063 & 0.00046 & 0.00044 & 0.00078 \\
\hline Tellurium & not determined & not determined & not determined & not determined & not determined \\
\hline Rhenium & $<0.0002$ & $<0.0002$ & $<0.0002$ & $<0.0002$ & $<0.0002$ \\
\hline Selenium & not determined & not determined & not determined & not determined & not determined \\
\hline Cobalt & 0.0016 & 0.0015 & 0.0008 & 0.0093 & 0.0008 \\
\hline Molybdenum & 0.0002 & 0.0004 & 0.0002 & 0.0004 & 0.0001 \\
\hline Nickel & 0.0007 & 0.0009 & 0.0003 & 0.0013 & 0.0010 \\
\hline Antimony & not determined & not determined & not determined & not determined & not determined \\
\hline Bismuth & not determined & 0.0047 & not determined & not determined & not determined \\
\hline Tin & 0.0021 & 0.0013 & not determined & not determined & 0.0025 \\
\hline Arsenic & 0.069 & 0.037 & 0.039 & 0.11 & 0.059 \\
\hline Manganese & 1.44 & 0.07 & 0.084 & 0.50 & 2.08 \\
\hline Phosphorus & 0.03 & 0.02 & 0.01 & 0.01 & 0.04 \\
\hline Fluorine & 0.01 & 0.011 & 0.013 & 0.015 & 0.01 \\
\hline Barium sulphate & 3.99 & сл. & 0.02 & 0.71 & 6.07 \\
\hline Titanium oxide & 0.16 & 0.06 & 0.05 & 0.14 & 0.17 \\
\hline Magnesium oxide & 1.66 & 0.10 & 0.13 & 0.52 & 2.40 \\
\hline Calcium oxide & 6.55 & 0.22 & 2.32 & 1.75 & 9.50 \\
\hline Silicon oxide & 12.75 & 0.78 & 0.61 & 3.64 & 18.56 \\
\hline Alumina & 2.16 & 0.28 & 0.35 & 2.48 & 3.04 \\
\hline Carbon monoxide & 13.30 & - & - & - & 13.50 \\
\hline
\end{tabular}

metals are formed at the dump. A secondary lithochemical halo of lead drawn using the Surfer software package is presented in Figure 1.

The carried out field observations and experimental studies have shown that heavy metals in acidic, oxidizing environments exist in (or transferred into) highly soluble forms, with polluting components migrating to considerable distances along the river network.

The storage of sulphide-containing rocks is associated with the danger of forming AMD due to pollution of atmospheric, surface or ground water filtered through a dump of sulphide-containing rocks or wastes by $\mathrm{H}^{+}$ions during the oxidation of sulphide minerals in an oxidizing environment, according to the following scheme: pyrite:

$$
\begin{gathered}
2 \mathrm{FeS}_{2}+7 \mathrm{O}_{2}+2 \mathrm{H}_{2} \mathrm{O} \rightarrow 2 \mathrm{FeSO}_{4}+2 \mathrm{H}_{2} \mathrm{SO}_{4} \\
4 \mathrm{FeSO}_{4}+2 \mathrm{H}_{2} \mathrm{SO}_{4}+\mathrm{O}_{2} \rightarrow 2 \mathrm{Fe}_{2}\left(\mathrm{SO}_{4}\right)_{3}+2 \mathrm{H}_{2} \mathrm{O}
\end{gathered}
$$

sphalerite:

$2 \mathrm{ZnS}+2 \mathrm{Fe}_{2}\left(\mathrm{SO}_{4}\right)_{3}+3 \mathrm{O}_{2}+2 \mathrm{H}_{2} \mathrm{O} \rightarrow 2 \mathrm{ZnSO}_{4}+$

$$
+4 \mathrm{FeSO}_{4}+2 \mathrm{H}_{2} \mathrm{SO}_{4}
$$

galena:

$2 \mathrm{PbS}+2 \mathrm{Fe}_{2}\left(\mathrm{SO}_{4}\right)_{3}+3 \mathrm{O}_{2}+2 \mathrm{H}_{2} \mathrm{O} \rightarrow 2 \mathrm{PbSO}_{4}+$

$$
+4 \mathrm{FeSO}_{4}+2 \mathrm{H}_{2} \mathrm{SO}_{4}
$$

A process of acid formation (rate and limits of $\mathrm{pH}$ decrease in $\mathrm{AMD}$, dependence of $\mathrm{H}^{+}$ion concentration on the time $p H=f(t))$ is determined by concentration of sulphide minerals in the rock; degree of crystallisation of sulphide minerals; crystallisation of pyrite; activity of biochemi- 
Table 2. Composition of samples from the exploring mine

\begin{tabular}{|c|c|c|c|c|c|c|c|c|}
\hline \multirow{2}{*}{$\begin{array}{l}\text { Type of } \\
\text { analysis }\end{array}$} & \multirow{2}{*}{$\begin{array}{c}\text { Defined charac- } \\
\text { teristics }\end{array}$} & \multicolumn{7}{|c|}{ Specimen burial depth, $m$} \\
\hline & & $0-0.4$ & $0.4-0.8$ & $0.8-1.2$ & $1.2-1.6$ & $1.6-2.0$ & $2.0-2.40$ & $2.40-3.0$ \\
\hline $\mathrm{XRF}$ & $\begin{array}{l}\text { Prevailing min- } \\
\quad \text { erals }\end{array}$ & $\begin{array}{c}\text { Pyrite, } \\
\text { quartz, sider- } \\
\text { ite, magnet- } \\
\text { ite, dolomite, } \\
\text { gypsum, } \\
\text { mica, kaolin- } \\
\text { ite, zinc sul- } \\
\text { phate, lead } \\
\text { sulphate }\end{array}$ & \begin{tabular}{|c|} 
Siderite, \\
quartz, \\
pyrite, \\
dolomite, \\
calcite, mica, \\
kaolinite, \\
calcium \\
sulphate \\
hemihydrate
\end{tabular} & $\begin{array}{c}\text { Pyrite, } \\
\text { quartz, } \\
\text { siderite, } \\
\text { calcium } \\
\text { sulphate } \\
\text { hemihydrate, } \\
\text { magnetite, } \\
\text { calcite, } \\
\text { kaolinite }\end{array}$ & $\begin{array}{c}\text { Pyrite, } \\
\text { quartz, } \\
\text { siderite, } \\
\text { magnetite, } \\
\text { calcite, } \\
\text { kaolinite, } \\
\text { dolomite, } \\
\text { mica }\end{array}$ & $\begin{array}{c}\text { Pyrite, } \\
\text { siderite, } \\
\text { dolomite, } \\
\text { quartz, } \\
\text { gypsum, } \\
\text { magnetite, } \\
\text { mica, } \\
\text { kaolinite }\end{array}$ & $\begin{array}{c}\text { Pyrite, } \\
\text { dolomite, } \\
\text { quartz, } \\
\text { siderite, } \\
\text { magnetite, } \\
\text { calcite, mica, } \\
\text { kaolinite }\end{array}$ & $\begin{array}{c}\text { Pyrite, } \\
\text { quartz, } \\
\text { siderite, } \\
\text { mica, } \\
\text { dolomite, } \\
\text { magnetite, } \\
\text { calcite, } \\
\text { sphalerite, } \\
\text { galena }\end{array}$ \\
\hline \multirow{9}{*}{$\begin{array}{l}\text { XRF, AAS, } \\
\text { and ICP }\end{array}$} & \multicolumn{8}{|c|}{ Element contents } \\
\hline & $\mathrm{Zn}, \mathrm{g} / \mathrm{kg}$ & 13 & 15 & 20 & 21 & 24 & 27 & 35 \\
\hline & $\mathrm{Pb}, \mathrm{g} / \mathrm{kg}$ & 4.5 & 6.5 & 6.9 & 11 & 12.4 & 18.0 & 25 \\
\hline & As, $\mathrm{mg} / \mathrm{kg}$ & 215 & 298 & 375 & 425 & 470 & 534 & 640 \\
\hline & $\mathrm{Cd}, \mathrm{mg} / \mathrm{kg}$ & 40 & 35 & 68 & 87 & 91 & 100 & 115 \\
\hline & $\mathrm{S}, \mathrm{g} / \mathrm{kg}$ & 170 & 185 & 198 & 200 & 211 & 235 & 240 \\
\hline & $\mathrm{Cu}, \mathrm{mg} / \mathrm{kg}$ & 180 & 192 & 213 & 230 & 301 & 266 & 320 \\
\hline & $\mathrm{Fe}, \mathrm{g} / \mathrm{kg}$ & 404.9 & 373.6 & 354.5 & 249.6 & 360.4 & 290.4 & 250.5 \\
\hline & $\mathrm{Ag}, \mathrm{mg} / \mathrm{kg}$ & 63 & 45 & 36 & 33 & 27 & 16 & 14 \\
\hline
\end{tabular}

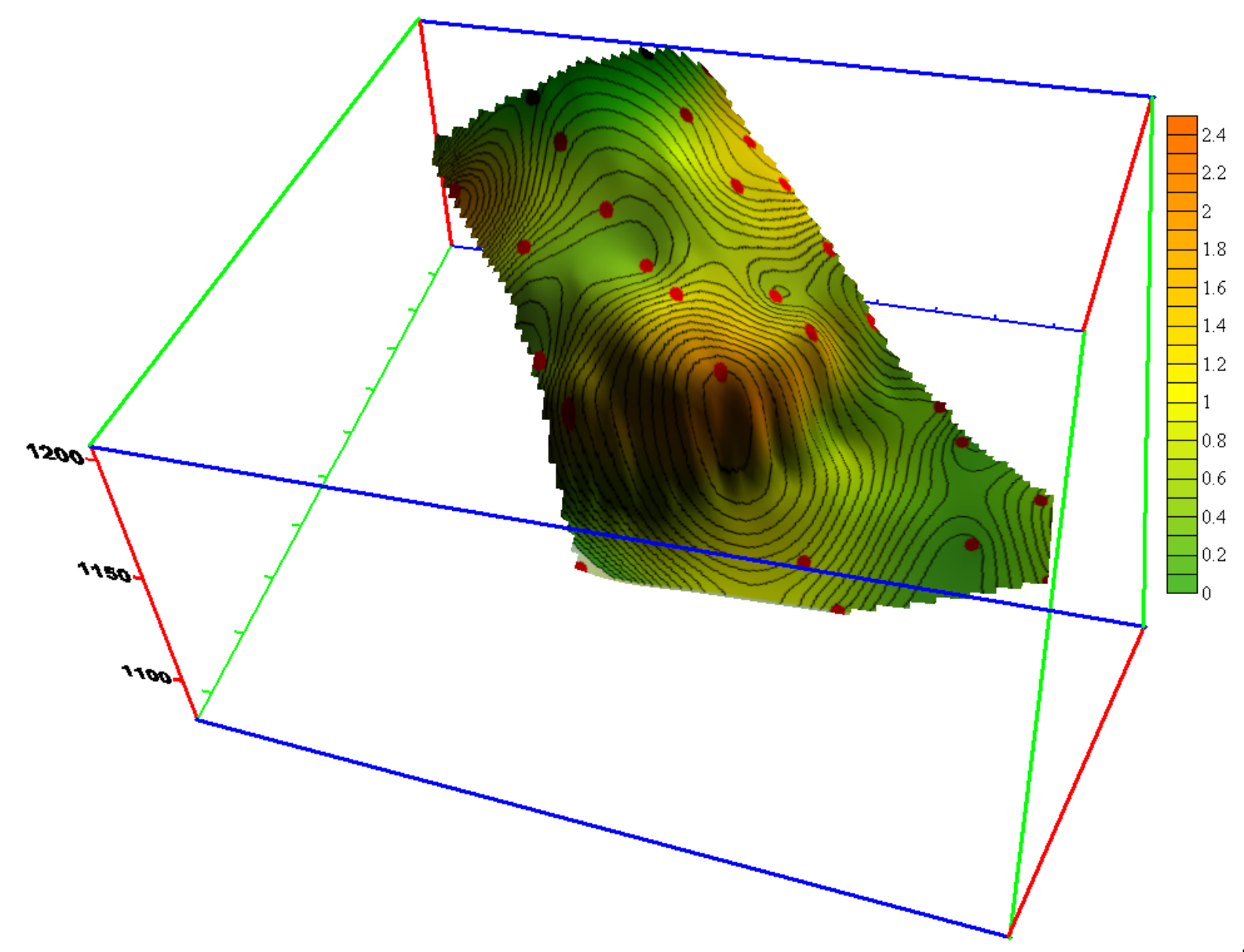

Fig. 1. Formation of the secondary lithochemical lead halo (the absolute height of the heap on the right, lead concentrations in technogenic deposits on the left, $\mathrm{g} / \mathrm{kg}$ ) 
cal processes; content of minerals that neutralise acidity in rocks or wastes and their type (carbonates, clay minerals, phosphates).

The ecological hazard of sulphide-containing rock dumps is most adequately assessed by an express method of acid indication, which allows to predict the time of AMD formation, a size and a contrast of litho- and hydrogeochemical pollution halos basing on values of acid potential and neutralisation potential formed by the rock.

The express method for determining the risk of AMD occurrence is based on studying:

- acid rock potential (AP),

- neutralisation rock potential (NP),

- coefficients of the potential danger of acid contamination of the territory NNPk and NNP'k:

$$
\begin{aligned}
& \mathrm{NNPk}=\mathrm{AP}-\mathrm{NP} \\
& \mathrm{NNP}{ }^{\prime} \mathrm{k}=\mathrm{NP} / \mathrm{AP}
\end{aligned}
$$

The acid rock potential is determined by the results of chemical rock analysis and recalculation of the sulphide sulphur $\mathrm{S}_{\text {sulph }}$ percentage into the percentage of sulphuric acid formed during rock weathering:

$$
\mathrm{S}_{\mathrm{H}_{2} \mathrm{SO}_{4}}(\%)=\mathrm{S}_{\text {sulph }}(\%) \frac{\text { M.m. } \mathrm{H}_{2} \mathrm{SO}_{4}}{\text { A.m.S }}
$$

where: $M$ and $M$ are the molecular and atomic masses, respectively.

The content of sulphuric acid is recalculated into AP, which, like NP, is measured in units equivalent to the tons of calcite $\mathrm{CaCO}_{3}$ spent for neutralising kilotons of sulphide-containing rocks ( $\mathrm{CaCO}_{3} / \mathrm{t}$ rock).

The neutralisation of sulphuric acid happens according to the following reaction equation:

$$
\mathrm{CaCO}_{3}+\mathrm{H}_{2} \mathrm{SO}_{4} \rightarrow \mathrm{CaSO}_{4}+\mathrm{CO}_{2}+\mathrm{H}_{2} \mathrm{O}
$$

The formula for calculating the acid potential is written as follows:

$$
\mathrm{AP}=\mathrm{S}_{\text {sulph }}(\%)
$$

The results of hydrochloric or sulphuric acid attack of the sulphide-containing rock up to a fixed $\mathrm{pH}$ value are used to calculate the neutralisation potential. If NNP $\geq 0$ and NNP ' $\geq 1$, the sulphide-containing rocks are not dangerous and do not have the ability to form an acid. In cases of NNPk $>0$ and NNP' $k<1$, rocks are dangerous and can form AMD.

- with NNP' $<\mathrm{S}$, rocks form an acid ( $\mathrm{S}$ is the content of sulphide sulphur in the sample);

- with $\mathrm{S}<\mathrm{NNP}$ ' $<1$, rocks have the potential to form acid in the future (Figure 2).

To determine the risk of AMD formation, the express method was used. The results are shown in Table 3 and Figure 2

The results of the express analysis show the contemporary high probability of AMD formation at the dumps near the exploratory mine, and the probability increases with depth. The relatively low acid potential of waste deposited in near-surface sediments is due to the already accomplished fact of oxidation of sulphide ores and leaching of heavy metals. Nevertheless, the technogenic danger of the dumps of exploratory mines remains over the 50-year period.

According to the research, the sulphide wastes of the Ozernoe deposit have a significant acid potential (up to $41.4 \mathrm{t} / 103 \mathrm{CaCO}_{3}$ ). At the concentration of sulphide sulphur in the wastes up to $10 \%$, there is a danger of forming more than 10 million tons of sulphuric acid. A lack of measures to protect soil and water resources will lead to infiltration of AMD through soils with the mobilisation of heavy metals from the body of the heap and formation of technochemical pollution halos.

\section{CONCLUSION}

Field observations and laboratory studies of the rocks of the exploratory mine have shown that the wastes of the Ozernoe deposit contain heavy

Table 3. Calculated acid and neutralization potentials for the tailings at the Ozernoe deposit

\begin{tabular}{|c|l|c|c|c|c|}
\hline \multirow{2}{*}{ № } & \multicolumn{1}{|c|}{ Properties } & \multicolumn{4}{c|}{ Specimen burial depth, m } \\
\cline { 3 - 6 } & \multicolumn{1}{|c|}{0} & 0.8 & 1.4 & 2.0 \\
\hline 1 & Ssulph, \% & 5.07 & 7.00 & 9.33 & 10.63 \\
\hline 2 & Acid potential AP, t/(103 t CaCO3) & 15.6 & 21.9 & 29.2 & 33.2 \\
\hline 3 & $\begin{array}{l}\text { Neutralization potential NP, t/(103 t } \\
\text { CaCO3) }\end{array}$ & 0 & 0.1 & 0.3 & 0.4 \\
\hline 4 & NNPK = AP - NP & 15.6 & 21.8 & 28.9 & 32.8 \\
\hline 5 & NNP'K = NP/AP & 0 & 0.004 & 0.010 & 0.012 \\
\hline
\end{tabular}




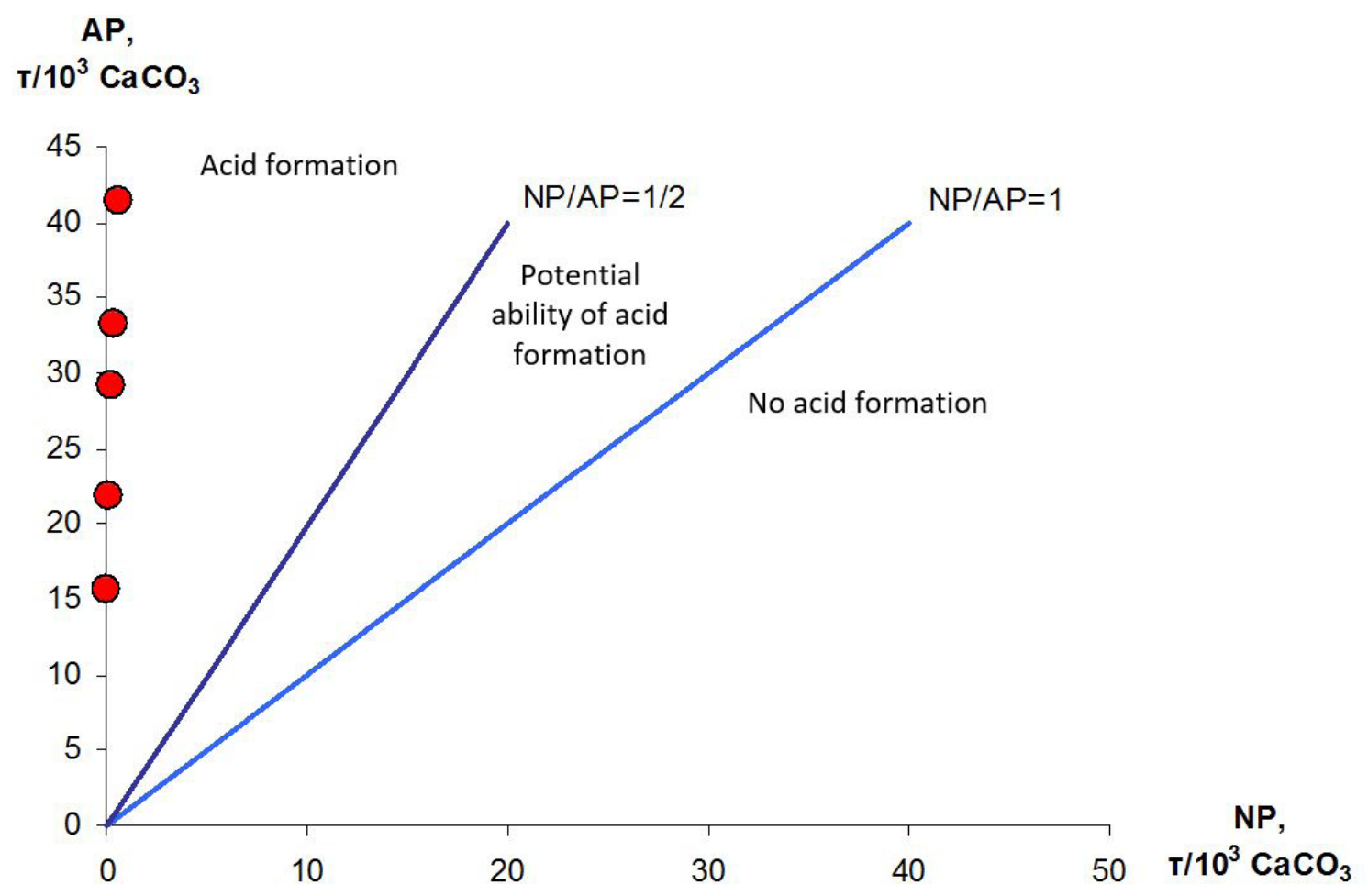

Fig. 2. Dependence of the ability of sulphide rocks of the Ozernoe deposit to form acid on NP and AP values

metals in the following concentrations: $13-35 \mathrm{~g} /$ $\mathrm{kg}$ of $\mathrm{Zn}, 4.5-25.0 \mathrm{~g} / \mathrm{kg}$ of Pb, $180-320 \mathrm{mg} / \mathrm{kg}$ of $\mathrm{Cu}$, and $215-640 \mathrm{mg} / \mathrm{kg}$ of As.

An assessment of landscape-geochemical conditions made it possible to establish that there is a danger of AMD formation in the vicinity of the spoils due to the oxidation of sulphide rocks. In addition, it is determined that more than $7.5 \mathrm{~kg}$ of zinc and more than $4.5 \mathrm{~kg}$ of lead are washed out annually from the spoil of the exploration tunnel.

The carried out researches of technogenic deposits of the exploratory mine allowed to make the forecast of the influence of the future extraction and processing wastes of the Ozernoe deposit. Thus, with the concentration of sulphide sulphur in the wastes up to $10 \%$ of the total content, there is a danger of forming over 10 million tons of sulphuric acid. A lack of measures to protect soil and water resources will lead to infiltration of acidic waters through soils with washing heavy metals out from the dump and the formation of technochemical pollution halos.

\section{Acknowledgments}

The analyses were performed using the equipment of the Common Use Centre of Saint Petersburg Mining University.

\section{REFERENCES}

1. Alekseenko, V.A., Maximovich, N.G., Alekseenko, A.V., 2017a. Geochemical Barriers for Soil Protection in Mining Areas. In: Bech, J., Bini, C., Pashkevich, M.A. (eds.) Assessment, Restoration and Reclamation of Mining Influenced Soils, Elsevier Inc. In press. DOI: 10.1016/ B978-0-12-809588-1.00009-8

2. Alekseenko, V.A., Shvydkaya, N.V., Alekseenko, A.V., Yashchinin, S.B., 2017b. Natural Restoration of Mining Influenced Soils in the Northwestern Caucasus, Russia. In: Bech, J., Bini, C., Pashkevich, M.A. (eds.) Assessment, Restoration and Reclamation of Mining Influenced Soils, Elsevier Inc. In press. DOI: 10.1016/ B978-0-12-809588-1.00010-4

3. Beloglazov, I.I., Suslov, A.P. Pedro, A.A., 2014. Change of constant component of phase voltage during melting of zirconium corundum. Tsvetnye Metally, 5, 86-89.

4. Bwapwa, J.K., Jaiyeola, A.T., Chetty, R., 2017. Bioremediation of acid mine drainage using algae strains: A review. South African Journal of Chemical Engineering. In press. DOI: 10.1016/j. sajce.2017.06.005

5. Cehlár, M., Domaracká, L., Šimko, I., Puzder, M., 2016. Mineral resource extraction and its political risks. Production Management and Engineer- 
ing Sciences - Scientific Publication of the International Conference on Engineering Science and Production Management, ESPM 2015, 39-43.

6. Favas, P.J.C., Sarkar, S.K., Rakshit, D., Venkatachalam, P., Prasad, M.N.V., 2016. Chapter 17: Acid Mine Drainages from Abandoned Mines: Hydrochemistry, Environmental Impact, Resource Recovery, and Prevention of Pollution. Environmental Materials and Waste, 413-462.

7. Fedorets, N.G., Medvedeva, M.V., 2009 Methods of studying soils of urban areas. Petrozavodsk, 84 p.

8. Grudev, A.P., 1995. Interactions in ecosystems: the factor of effective stability of minerals. Geological research and protection of mineral resources, 2, 3-8.

9. Gumenik, I.L., Matveev, A.S., Panasenko, A.I., 1988. Classification of technogenic formations in open mining. Gornyi Zhurnal, 12.

10. Han, Y.-S., Youm, S.-J., Oh, C., Cho, Y.-C., Ahn, J.S., 2017. Geochemical and eco-toxicological characteristics of stream water and its sediments affected by acid mine drainage. Catena, 148, 52-59.

11. Kefeni, K.K., Msagati, T.A.M., Mamba, B.B., 2017. Acid mine drainage: Prevention, treatment options, and resource recovery: A review. Journal of Cleaner Production, 151, 475-493.
12. Nleya, Y., Simate, G. S., Ndlovu, S., 2016. Sustainability assessment of the recovery and utilisation of acid from acid mine drainage. Journal of Cleaner Production, 113, 17-27.

13. Pashkevich, M.A., 2017. Classification and Environmental Impact of Mine Dumps. In: Bech, J., Bini, C., Pashkevich, M.A. (eds.) Assessment, Restoration and Reclamation of Mining Influenced Soils, Elsevier Inc. In press. DOI: 10.1016/ B978-0-12-809588-1.00001-3

14. Pashkevich, M.A., Petrova, T.A., 2015. New isolation materials for technogenic deposits conservation. Obogashchenie Rud 6, pp. 46-49.

15. Pashkevich, M.A., Petrova, T.A., 2017. Reclamation by Containment: Polyethylene-Based Solidification. In: Bech, J., Bini, C., Pashkevich, M.A. (eds.) Assessment, Restoration and Reclamation of Mining Influenced Soils, Elsevier Inc. In press. DOI: 10.1016/B978-0-12-809588-1.00008-6

16. Pavolová, H., Khouri, S., Cehlár, M., Domaracká, L., Puzder, M., 2016. Modelling of copper and zinc adsorption onto zeolite. Metalurgija, 55 (4), 712-714.

17. Simate, G.S., Ndlovu, S., 2014. Acid mine drainage: Challenges and opportunities. Journal of Environmental Chemical Engineering, 2 (3), 1785-1803. 